\title{
4 \\ LA EMERGENCIA DE LOS HIPERMEDIOS ONLINE ¿UN NUEVO DESAFíO PARA LA TEORÍA/METODOLOGÍA SEMIÓTICA?
}

Pedro Silva 


\section{RESUMEN}

El surgimiento de tres hipermedias online El Territorio Digital, Primera Edición Web y Noticias de la Calle Edición Web, versiones electrónicas de tres medios locales gráficos impresos El Territorio, Primera Edición y Noticias de la Calle (todos editados en la ciudad de Posadas, Misiones, Argentina) constituye un fenómeno de manifestación de sentido susceptible de ser interpretado desde la perspectiva semiótica. Emergencia de un proceso Semiótico hipermediatizado relativamente «novedoso» cuyo abordaje demanda una revisión crítica de ciertos aspectos teóricos-metodológicos del campo semiótico. Trabajo de actualización que permitiría la readecuación y la construcción de nuevas categorías que habiliten una interpretación posible del modo en que funcionan estos megadispositivos hipertextuales, multimediales e interactivos online desde un enfoque que reconoce su inscripción en procesos semióticos complejos de continuidades y transformaciones en los cuales se regeneran formatos, y discursos.

La contrastación de los formatos gráficos en papel y de los megaformatos hipermediáticos online en soporte electrónico (pantalla) es un camino posible para un rastreo de ciertos indicios de reconstituciones generadas como consecuencia de su inserción en un proceso de continuidades y transformaciones.

\section{PALABRAS CLAVE}

$>$ dispositivo

$>$ medios

$>$ hipermedios

$>$ semiosis 


\section{ABSTRACT}

The emergence of three different hypermedia: El Territorio Digital, Primera Edición Web y Noticias de la Calle Edición Web, online versions of three local newspapers, El Territorio, Primera Edición y Noticias de la Calle - all of the medited in Posadas, Misiones, Argentina - constitute a phenomen a susceptible to be studied from the semiotic perspective. This hyper-mediatized relatively «new» semiotic process demands a critical review of several theoretical-methodological aspects in the semiotics field. The work would allow the re-adequacy and construction of new categories that able possible interpretations of the way in wich these mega hypertextual, multimedia, interactive online «dispositives» work, from a perspective that recognizes its inscription in complex semiotic processes of transformations and continuities in wich formats and discourses are regenerated.

The contrast among paper format and hypermedia online format, establish a possible way to trace some hints of the changes generated as a consequence of its insertion in the continuity-transformation process.

\section{KEY WORDS}

$>$ dispositive

$>$ media

$>$ hypermedia

$>$ semiosis 